Available online at:

Edu Masda Journal

ISSN (Print) 2597-4572 ISSN (Online) 2715-5269

\title{
EVALUASI PENGADAAN OBAT BERDASARKAN PELAYANAN DISTRIBUTOR FARMASI DI RSIA KEMANG MEDICAL CARE JAKARTA SELATAN PERIODE JULI DESEMBER 2019
}

Nur Hasanah, Nurwulan Adi Ismaya, Lela Kania Rahsa Puji, Bayu Prihantoro

${ }^{5}$ STIKes Kharisma Persada, Jl. Pajajaran No 1 Pamulang, Tangerang selatan, Indonesia

\begin{tabular}{|c|c|}
\hline ARTICLE INFORMATION & $\begin{array}{llllllll}A & B & S & T & R & A & C & T\end{array}$ \\
\hline $\begin{array}{l}\text { Nur Hasanah } \\
\text { Corresponding } \\
\text { E-mail: nurhasanah@masda.ac.id }\end{array}$ & \multirow{2}{*}{$\begin{array}{l}\text { Drug management is one of the pharmaceutical management in the Hospital } \\
\text { which is very important in the overall service. Stages of drug management } \\
\text { in the Hospital include the stages of selection, planning, procurement, } \\
\text { receiving, storage, distribution, and use of drugs. Patnership with } \\
\text { Pharmacy Wholesalers needs special attention because it can influence the } \\
\text { procurement of pharmaceutical preparations in hospitals. This study aimed } \\
\text { to the determine the process of prucurement of drugs based on distributor } \\
\text { services (Pharmaceutical Wholesalers) at RSIA Kemang Medical Care. } \\
\text { Retrospective data collection methods. The sample includes data on Drug } \\
\text { Purchase Requests for the period July } 1 \text { - December } 312019 \text { for weekly } \\
\text { defects made by the Pharmacy Installation of RSIA Kemang Medical Care } \\
\text { every Monday, totaling } 302 \text { samples. Service Level based on the type / order } \\
\text { item for } 13 \text { Pharmaceutical Wholesalers (PBF) 88,55\% - 98,43\% Supplier } \\
\text { Service Level based on the precentage of the number of pharmaceutical } \\
\text { preparations there are Pharmaceutical Wholesalers (PBF) that have never } \\
\text { been in accordance with the requested shipment, ranging from } 2 \% \text { - } 100 \% \text {. } \\
\text { The factors that cause incomepatibilty are empty stoc at distributors and } \\
\text { there is a shortage in shipping pahrmaceutical preparations. }\end{array}$} \\
\hline $\begin{array}{l}\text { Keywords: } \\
\text { - } \quad \text { Service Level Supplier, } \\
\text { - } \quad \text { Pharmaceutical Wholesalers } \\
\text { - } \quad \text { Drug management }\end{array}$ & \\
\hline $\begin{array}{l}\text { Kata Kunci: } \\
\text { - } \quad \text { Kepuasan pasien; } \\
\text { - } \quad \text { Tingkat pelayanan kefarmasian; } \\
\text { - } \quad \text { Pengelolaan obat; }\end{array}$ & $\begin{array}{l}\text { Pengelolaan obat merupakan salah satu management farmasi di Rumah } \\
\text { Sakit yamg sangat penting dalam penyediaan pelayanan secara keseluruhan. } \\
\text { Kemitraan dengan Pedagang Besar Farmasi perlu mendapat perhatian } \\
\text { khusus karena dapat berpengaruh dalam pengadaan sediaan farmasi di } \\
\text { Rumah Sakit. Penelitian ini ditujukan untuk mengetahui proses pengadaan } \\
\text { obat berdasarkan pelayanan distributor (Pedagang Besar Farmasi) di RSIA } \\
\text { Kemang Medical Care. Metode pengumpulan data secara Retrospektif. } \\
\text { Sampel meliputi data Permintaan Pembelian obat periode } 1 \text { Juli - } 31 \\
\text { Desember } 2019 \text { untuk defekta mingguan yang dibuat oleh Instalasi Farmasi } \\
\text { RSIA Kemang Medical Care setiap hari senin, berjumlah } 302 \text { sampel. } \\
\text { Service Level Supplier berdasarkan jeni / item pesanan untuk } 13 \text { Pedagang } \\
\text { Besar Farmasi (PBF) adalah } 88,55 \% \text { - } 98,43 \% \text {. Service Level Supplier } \\
\text { berdasarkan presentase jumlah sediaan farmasi terdapat Pedagang Besar } \\
\text { Farmasi (PBF) pernah dalam pengiriman jumlahnhya tidak sesuai dengan } \\
\text { yang diminta yaitu berkisar } 2 \% \text { - } 100 \% \text {. Faktor yang menyebabkan ketidak } \\
\text { sesuaian yakni stok kosong pada distributor dan terdapat kekurangan dalam } \\
\text { pengiriman sediaan farmasi. }\end{array}$ \\
\hline
\end{tabular}




\section{PENDAHULUAN}

Pengelolaan obat merupakan salah satu manajemen farmasi di rumah sakit yang sangat penting dalam penyediaan pelayanan secara keseluruhan, karena ketidakefisienan dan ketidak lancaran pengelolaan obat akan memberikan dampak negatif terhadap rumah sakit, baik secara medik, sosial maupun secara ekonomi.

Berdasarkan hasil penelitian Amiati Pratiwi (2009), Stock Out Obat di Gudang Perbekalan Kesehatan Rumah Sakit Islam Cempaka Putih Jakarta Pada Triwulan I Tahun 2009 terdapat sebesar 5,70\% permintaan obat yang tidak terlayani dari gudang logistik ke depo farmasi rumah sakit disebabkan karena tidak tersedianya obat atau terjadinya kekosongan obat di gudang logistik.

Secara garis besar, tahapan pengelolaan obat di Rumah Sakit meliputi tahap pemilihan, perencanaan, pengadaan, penerimaan, penyimpanan, pendistribusian, serta penggunaaan obat. Pengelolaan sediaan farmasi,alat kesehatan dan bahan medis habis pakai di Rumah Sakit harus dilakukan oleh Instalasi Farmasi sistem satu pintu.

Pengelolaan perbekalan kesehatan yang berupa sediaan farmasi dan alat kesehatan dilaksanakan dengan memperhatikan pemenuhan kebutuhan, kemanfaatan, harga, dan faktor yang berkaitan dengan pemerataan penyediaan perbekalan kesehatan. Perencanaan merupakan kegiatan untuk menentukan jumlah dan periode pengadaan sediaan farmasi sesuai dengan hasil kegiatan pemilihan untuk menjamin terpenuhinya kriteria tepat jenis, tepat jumlah, tepat waktu dan efisien. Pengadaan merupakan kegiatan yang dimaksudkan untuk merealisasikan perencanaan kebutuhan.Pengadaan yang efektif harus menjamin ketersediaan, jumlah, dan waktu yang tepat dengan harga yang terjangkau dan sesuai standar mutu. Pengendaliaan juga diperlukan pada tahap pengadaan yaitu dalam pemilihan metode pengadaan, pemantauan spesifikasi perjanjian dan pemantauan status pemesanan serta penentuan Pedagang Besar Farmasi (PBF). Kemitraan dengan 
Pedagang Besar Farmasi perlu mendapat perhatian khusus karena dapat berpengaruh dalam pengadaan sediaan farmasi di rumah sakit.

Sejauh ini masalah yang sering ditemukan yang berkaitan dengan Pedagang Besar Farmasi (PBF) adalah ketidaktepatan waktu dalam penerimaan dan ketidak sesuaian pesanan dengan jumlah obat yang dikirim. Tidak terpenuhinya pesanan dari Pedagang Besar Farmasi (PBF) dapat berakibat ketidak puasan bagi pasien dan dapat menimbulkan dampak yang negatif bagi Rumah Sakit.

Berdasarkan uraian di atas, proses pengadaan obat dalam hal pelayanan oleh Pedagang Besar Farmasi (PBF) harus mendapatkan perhatian khusus, mengingat di RSIA Kemang Medical Care sering terjadi kekosongan obat. Hal ini sering kali karena keterlambatan dari pihak Pedagang Besar Farmasi (PBF) dalam mengirimkan obat atau stock kosong pada saat pemesanan. Oleh karena itu, peneliti tertarik untuk melakukan penelitian tentang "Evaluasi Pengadaan Obat Berdasarkan Pelayanan Distributor Farmasi di RSIA Kemang Medical Care

\section{METODE}

Dalam penelitian ini, peneliti menggunakan metode pengumpulan data secara Retrospektif dengan cara mengumpulkan dan menganalisa data dari surat permintaan pembelian dan lembar penerimaan barang periode 1 Juli-31 Desember 2019. Populasi meliputi data permintaan pembelian periode 1 Juli - 31 Desember 2019 di Gudang Farmasi RSIA Kemang Medical Care Jakarta Selatan berjumlah 1226 lembar permintaan pembelian obat.

Sampel meliputi data Permintaan Pembelian obat periode 1 Juli - 31 Desember 2019 untuk defekta mingguan yang dibuat oleh Instalasi Farmasi RSIA Kemang Medical Care setiap hari senin, sampel dihitung dengan menggunakan rumus slovin berjumlah 302 sampel. Perhitungan sampel dengan menggunakan rumus slovin dengan margin of error yang ditetapkan adalah 5\% adalah 302 sampel

Data yang diperoleh dalam penelitian ini merupakan data primer. Data diambil dari surat permintaan 
pembelian disetiap hari senin yang dibuat oleh bagian pengadaan rumah sakit dan lembar penerimaan barang yang dibuat oleh gudang farmasi sesuai dengan faktur yang dikeluarkan oleh Pedagang Besar Farmasi (PBF).

Pengolahan dan Analisis Data pada penelitian ini dilakukan dengan cara: Melakukan observasi di bagian pengadaan, Mengumpulkan surat permintaan pembelian sesuai permintaan dari Instalasi Farmasi Rumah Sakit untuk pesanan rutin seminggu sekali setiap hari senin, faktur penjualan dari Pedagang Besar Farmasi (PBF), dan lembar penerimaan barang periode $1 \mathrm{Juli}-31$ Desember 2019, Mencatat lead time obat yang dipesan dengan yang datang dari Pedagang Besar Farmasi (PBF), Mencatat kesesuaian jenis serta jumlah obat dan surat permintaan pembelian yang dibandingkan dengan lembar penerimaan barang, Mencatat nama Pedagang Besar Farmasi (PBF) yang tingkat pelayanannya kurang dilihat dari waktu, jumlah, dan jenis obat yang tidak sesuai, Mencatat faktorfaktor penyebab terjadinya keterlambatan dab ketidak sesuaian jumlah atau jenis item barang yang dikirim oleh Pedagang Besar Farmasi (PBF), Menyajikan data dalam bentuk table, Menganalisa data dengan menghitung presentase service level supplier

\section{HASIL}

\section{Lead time barang datang dari}

mulai pemesanan sampai dengan penerimaan.

Waktu yang dibutuhkan oleh distributor untuk pemesanan sampai dengan barang diterima periode 01 juli - 31 Desember 2019 adalah sebagai berikut :

Tabel 1. Lead time Barang Datang periode 01 Juli - 31 Desember 2019

\begin{tabular}{lccc}
\hline Nama PBF & $\begin{array}{c}\text { Frekuensi } \\
\text { Pemesanan }\end{array}$ & \multicolumn{2}{c}{ Service Level Supplier } \\
AAM & & Tepat Waktu & Terlambat \\
AMS & 51 & 49 & $2(5$ hari $)$ \\
APL & 36 & 36 & - \\
BSP & 40 & 39 & $1(4$ hari $)$ \\
DNR & 38 & 37 & $1(4$ hari $)$ \\
ENSEVAL & 8 & 8 & - \\
GAW & 41 & 41 & - \\
\hline
\end{tabular}




\begin{tabular}{lccc}
\hline KBF & 16 & 14 & 2 (4 hari) \\
KF & 9 & 9 & - \\
MBS & 8 & 8 & - \\
MPI & 9 & 8 & 1 (4 hari) \\
PARIT & 5 & 5 & - \\
PV & 6 & 5 & $1(4$ hari $)$ \\
Total & 302 & 294 & 8 \\
Presentase & & $97,35 \%$ & $2,64 \%$ \\
\hline
\end{tabular}

\section{Persentase kesesuaian jenis}

pesanan yang diterima dengan

\section{standar service level supplier}

Setelah melakukan pengolahan data, dapat diketahui presentase kesesuaian jenis maupun item pesanan yang dikirim oleh Pedagang Besar Farmasi (PBF)

diterima oleh gudang farmasi dengan pesanan periode 1 Juli - 31 Desmber 2019 dengan data sebagai berikut

Tabel 2.Kesesuaian Jenis/Item Pesanan

\begin{tabular}{|c|c|c|c|c|c|c|c|c|c|}
\hline $\begin{array}{l}\text { Nama } \\
\text { PBF } \\
\text { PT }\end{array}$ & $\begin{array}{c}\text { Jml. } \\
\text { PO }\end{array}$ & $\begin{array}{l}\text { Jml } \\
\text { yg } \\
\text { sesuai } \\
\text { PO }\end{array}$ & $\begin{array}{l}\text { Jml } \\
\text { yg } \\
\text { tidak } \\
\text { sesuai } \\
\text { PO }\end{array}$ & $\begin{array}{l}\text { Item yg } \\
\text { dipesan }\end{array}$ & $\begin{array}{l}\text { Item yg } \\
\text { tidak } \\
\text { sesuai } \\
\text { PO }\end{array}$ & $\begin{array}{l}\text { Item } \\
\text { yg } \\
\text { sesuai } \\
\text { PO }\end{array}$ & $\%$ SLS & $\begin{array}{c}\text { Rata } \% \\
\text { SLS }\end{array}$ & $\begin{array}{l}\text { Ket. } \\
\text { Hasil }\end{array}$ \\
\hline \multirow[t]{11}{*}{ AAM } & 51 & 41 & & & & & & & \\
\hline & & & 10 & 1) 19 & 3 & 16 & $84,21 \%$ & & \\
\hline & & & & 2) 3 & 1 & 2 & $66,67 \%$ & & \\
\hline & & & & 3) 20 & 4 & 16 & $80 \%$ & & \\
\hline & & & & 4) 7 & 2 & 5 & $71,42 \%$ & & \\
\hline & & & & 5) 4 & 3 & 1 & $25 \%$ & & \\
\hline & & & & 6) 3 & 2 & 1 & $33,34 \%$ & $94,35 \%$ & Baik \\
\hline & & & & 7) 7 & 1 & 6 & $85,71 \%$ & & \\
\hline & & & & 8) 14 & 2 & 12 & $85,71 \%$ & & \\
\hline & & & & 9) 13 & 1 & 12 & $92,30 \%$ & & \\
\hline & & & & 10) 16 & 2 & 14 & $87,50 \%$ & & \\
\hline \multirow[t]{2}{*}{ AMS } & 36 & 23 & & & & & & & \\
\hline & & & 13 & 1) 8 & 2 & 6 & $75 \%$ & & \\
\hline
\end{tabular}




\begin{tabular}{|c|c|c|c|c|}
\hline 2) 12 & 1 & 11 & $91,67 \%$ & \\
\hline 3) 34 & 2 & 32 & $94,11 \%$ & $91,84 \%$ \\
\hline 4) 40 & 1 & 39 & $97,50 \%$ & \\
\hline 5) 40 & 4 & 36 & $90 \%$ & \\
\hline 6) 17 & 3 & 14 & $82,35 \%$ & \\
\hline 7) 39 & 7 & 32 & $82,05 \%$ & \\
\hline 8) 11 & 3 & 8 & $72,72 \%$ & \\
\hline 9) 2 & 1 & 1 & $50 \%$ & \\
\hline 10) 35 & 21 & 14 & $40 \%$ & \\
\hline 11) 10 & 4 & 6 & $60 \%$ & \\
\hline 12) 15 & 3 & 12 & $80 \%$ & \\
\hline 13) 22 & 2 & 20 & $90,90 \%$ & \\
\hline
\end{tabular}

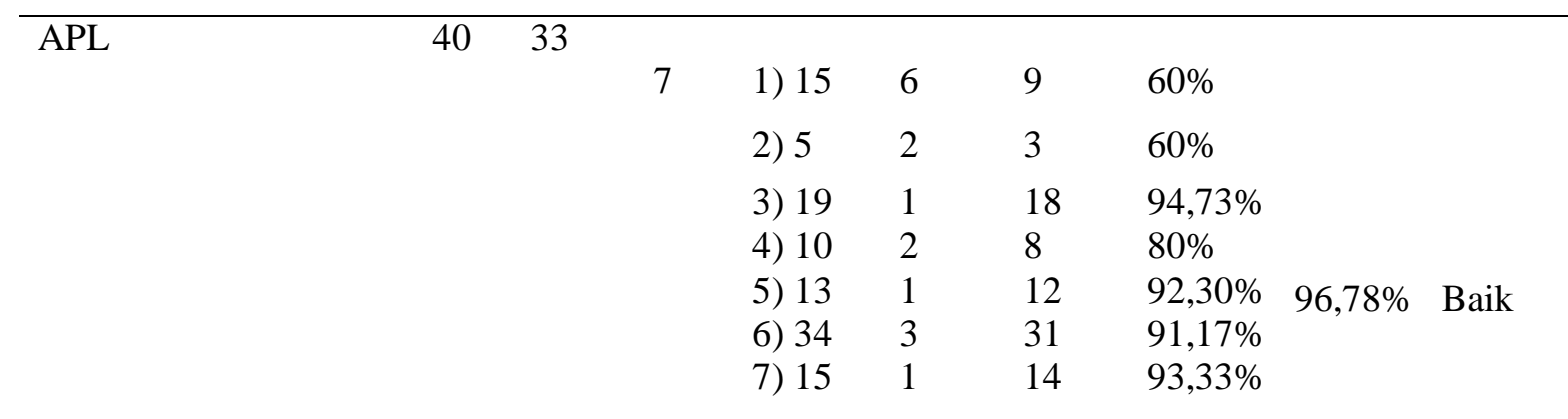

\begin{tabular}{|c|c|c|c|c|c|c|c|c|c|}
\hline \multirow[t]{12}{*}{$\overline{\mathrm{BSP}}$} & 38 & 27 & & & & & & \multirow{12}{*}{\multicolumn{2}{|c|}{$97,02 \%$}} \\
\hline & & & 11 & 1) 28 & 2 & 26 & $92,85 \%$ & & \\
\hline & & & & 2) 41 & 1 & 40 & $97,56 \%$ & & \\
\hline & & & & 3) 14 & 1 & 13 & $92,85 \%$ & & \\
\hline & & & & 4) 42 & 1 & 41 & $97,61 \%$ & & \\
\hline & & & & 5) 33 & 1 & 32 & $96,96 \%$ & & \\
\hline & & & & 6) 5 & 1 & 4 & $80 \%$ & & \\
\hline & & & & 7) 32 & 2 & 30 & $93,75 \%$ & & \\
\hline & & & & 8) 10 & 2 & 8 & $80 \%$ & & \\
\hline & & & & 9) 4 & 1 & 3 & $75 \%$ & & \\
\hline & & & & 10) 35 & 3 & 32 & $91,42 \%$ & & \\
\hline & & & & 11) 9 & 1 & 8 & $88,89 \%$ & & \\
\hline \multirow[t]{2}{*}{$\overline{\mathrm{DNR}}$} & 8 & 7 & & & & & & \multirow[b]{2}{*}{$9843 \%$} & \\
\hline & & & 1 & 1) 8 & 1 & 7 & $87,5 \%$ & & \\
\hline
\end{tabular}




\begin{tabular}{|c|c|c|c|c|c|c|c|c|c|c|}
\hline & & & & 7 & $\begin{array}{l}\text { 1) } 9 \\
\text { 2) } 27 \\
\text { 3) } 21 \\
\text { 4) } 8 \\
\text { 5) } 4 \\
\text { 6) } 5 \\
\text { 7) } 9\end{array}$ & \begin{tabular}{l|l}
1 & \\
1 & \\
1 & \\
1 & \\
1 & \\
1 & \\
1 &
\end{tabular} & $\begin{array}{l}8 \\
26 \\
20 \\
7 \\
3 \\
4 \\
8\end{array}$ & $\begin{array}{l}88,89 \% \\
96,29 \% \\
95,23 \% \\
87,5 \% \\
75 \% \\
80 \% \\
88,89 \%\end{array}$ & $97,84 \%$ & Baik \\
\hline AW & 35 & 19 & 16 & $\begin{array}{l}\text { 1) } 9 \\
\text { 2) } 59 \\
\text { 3) } 10 \\
\text { 4) } 57 \\
\text { 5) } 59 \\
\text { 6) } 56 \\
\text { 7) } 49 \\
\text { 8) } 29 \\
\text { 9) } 17 \\
\text { 10) } 46 \\
\text { 11) } 24 \\
\text { 12) } 33 \\
\text { 13) } 16 \\
\text { 14) } 40 \\
\text { 15) } 31 \\
\text { 16) } 43\end{array}$ & $\begin{array}{l}2 \\
4 \\
1 \\
5 \\
7 \\
1 \\
5 \\
5 \\
2 \\
3 \\
2 \\
2 \\
1 \\
1 \\
1 \\
2\end{array}$ & $\begin{array}{l}7 \\
55 \\
9 \\
52 \\
52 \\
55 \\
44 \\
24 \\
15 \\
43 \\
22 \\
31 \\
15 \\
39 \\
30 \\
41\end{array}$ & $\begin{array}{l}77,78 \% \\
93,22 \% \\
90 \% \\
91,22 \% \\
88,13 \% \\
98,21 \% \\
89,79 \% \\
82,75 \% \\
88,23 \% \\
93,47 \% \\
91,67 \% \\
93,93 \% \\
93,75 \% \\
97,5 \% \\
96,77 \% \\
95,34 \%\end{array}$ & $96,05 \%$ & & Baik \\
\hline $\mathrm{KBF}$ & 16 & 13 & 3 & $\begin{array}{l}\text { 1) } 8 \\
\text { 2) } 9 \\
\text { 3) } 7\end{array}$ & $\begin{array}{l}2 \\
4 \\
1\end{array}$ & $\begin{array}{l}6 \\
5 \\
6\end{array}$ & $\begin{array}{l}75 \% \\
55.56 \% \\
85,71 \%\end{array}$ & $94,76 \%$ & & Baik \\
\hline & & & 2 & $\begin{array}{l}\text { 1) } 6 \\
\text { 2) } 9\end{array}$ & $\begin{array}{l}3 \\
2\end{array}$ & $\begin{array}{l}3 \\
7\end{array}$ & $\begin{array}{l}50 \% \\
77,78 \%\end{array}$ & $91,97 \%$ & & Baik \\
\hline MBS & 8 & 7 & 1 & 1) 3 & 1 & 2 & $66,67 \%$ & $95,83 \%$ & & Baik \\
\hline MPI & 9 & 7 & 2 & $\begin{array}{l}\text { 1) } 22 \\
\text { 2) } 6\end{array}$ & $\begin{array}{l}1 \\
2\end{array}$ & $\begin{array}{l}21 \\
4\end{array}$ & $\begin{array}{l}95,45 \% \\
66,67 \%\end{array}$ & $95,79 \%$ & & Baik \\
\hline Parit & 5 & 2 & 3 & $\begin{array}{l}\text { 1) } 8 \\
\text { 2) } 8 \\
\text { 3) } 9\end{array}$ & $\begin{array}{l}1 \\
3 \\
2\end{array}$ & $\begin{array}{l}7 \\
5 \\
7\end{array}$ & $\begin{array}{l}87,5 \% \\
62,5 \% \\
77,78 \%\end{array}$ & $85,55 \%$ & & Baik \\
\hline PV & 6 & 4 & 2 & $\begin{array}{l}\text { 1) } 8 \\
\text { 2) } 3\end{array}$ & $\begin{array}{l}2 \\
1\end{array}$ & $\begin{array}{l}6 \\
2\end{array}$ & $\begin{array}{l}75 \% \\
66,67 \%\end{array}$ & $90,27 \%$ & & Baik \\
\hline
\end{tabular}

Presentase kesesuaian jumlah pesanan sediaan farmasi yang diterima setelah melakukan

pengolahan data 
Dapat diketahui presentase

kesesuaian jumlah pesanan yang

dikirim oleh Pedagang Besar Farmasi

(PBF) yang selanjutnya diterima oleh gudang farmasi dengan pesanan

periode 1 Juli - 31 Desember 2019

dengan data sebagai berikut :

Tabel 3.Jumlah Sediaan Tidak Sesuai Pesanan PT. AAM

\begin{tabular}{|c|c|c|c|c|c|c|c|}
\hline $\begin{array}{l}\text { Nama } \\
\text { PBF } \\
\text { (PT) }\end{array}$ & $\begin{array}{l}\text { Jml } \\
\text { PO }\end{array}$ & $\begin{array}{l}\text { Jml } \\
\text { yg } \\
\text { sesuai } \\
\text { PO }\end{array}$ & $\begin{array}{l}\text { Item } \\
\text { yg jml } \\
\text { tdk } \\
\text { sesuai }\end{array}$ & $\begin{array}{l}\text { Item } \\
\text { yg } \\
\text { dipesa } \\
\mathrm{n}\end{array}$ & $\begin{array}{l}\text { Item yg tdk } \\
\text { sesuai jml }\end{array}$ & $\begin{array}{l}\% \text { jml } \\
\text { yg tdk } \\
\text { sesuai }\end{array}$ & $\begin{array}{l}\text { Ket. } \\
\text { Hasil }\end{array}$ \\
\hline \multirow[t]{22}{*}{ AAM } & 51 & 41 & \multirow{22}{*}{10} & & & & \\
\hline & & & & 1) 19 & Rhinofed syr & $50 \%$ & BURUK \\
\hline & & & & \multirow{6}{*}{$\begin{array}{l}\text { 2) } 3 \\
\text { 3) } 20\end{array}$} & Pedialyte Sol & $100 \%$ & BURUK \\
\hline & & & & & Elidel $\mathrm{Cr}$ & $50 \%$ & BURUK \\
\hline & & & & & Mederma $\mathrm{Cr}$ & $100 \%$ & BURUK \\
\hline & & & & & $\begin{array}{l}\text { Tarivid eye } \\
\text { drop }\end{array}$ & $100 \%$ & BURUK \\
\hline & & & & & Inbumin & $100 \%$ & BURUK \\
\hline & & & & & $\begin{array}{l}\text { Dumin250mgs } \\
\text { upp }\end{array}$ & $100 \%$ & BURUK \\
\hline & & & & \multirow{3}{*}{ 4) 7} & Folilac Kapsul & $100 \%$ & BURUK \\
\hline & & & & & Apolar Cr & $100 \%$ & BURUK \\
\hline & & & & & $\begin{array}{l}\text { Doxycyclin } \\
\text { Kap }\end{array}$ & $100 \%$ & BURUK \\
\hline & & & & \multirow[t]{2}{*}{ 5) 4} & Mederma $\mathrm{Cr}$ & $100 \%$ & BURUK \\
\hline & & & & & Elidel Cr & $100 \%$ & BURUK \\
\hline & & & & \multirow{3}{*}{ 6) 3} & Pedialyte Sol & $50 \%$ & BURUK \\
\hline & & & & & Atopiclair $\mathrm{Cr}$ & $100 \%$ & BURUK \\
\hline & & & & & $\begin{array}{l}\text { Terramycin } \\
\text { Salep }\end{array}$ & $100 \%$ & BURUK \\
\hline & & & & 7) 7 & $\begin{array}{l}\text { Stesolid 10mg } \\
\text { sup }\end{array}$ & $100 \%$ & BURUK \\
\hline & & & & \multirow[t]{2}{*}{ 8) 14} & Apolar N Cr & $100 \%$ & BURUK \\
\hline & & & & & Seloxy Tab & $50 \%$ & BURUK \\
\hline & & & & 9) 13 & Mederma $\mathrm{Cr}$ & $100 \%$ & BURUK \\
\hline & & & & \multirow[t]{2}{*}{ 10) 16} & $\begin{array}{l}\text { Anvomer B6 } \\
\text { Tab }\end{array}$ & $100 \%$ & BURUK \\
\hline & & & & & Lycoxy Tab & $100 \%$ & BURUK \\
\hline
\end{tabular}


Tabel 4. Jumlah Sediaan Tidak Sesuai Pesanan PT. AMS

\begin{tabular}{|c|c|c|c|c|c|c|c|}
\hline $\begin{array}{l}\text { Nama } \\
\text { PBF } \\
\text { (PT) }\end{array}$ & $\begin{array}{l}\text { Jml } \\
\text { PO }\end{array}$ & $\begin{array}{l}\text { Jml yg } \\
\text { sesuai PO }\end{array}$ & $\begin{array}{l}\text { Item yg } \\
\text { jml tdk } \\
\text { sesuai }\end{array}$ & $\begin{array}{l}\text { Item } \\
\text { yg } \\
\text { dipesa } \\
\mathrm{n}\end{array}$ & $\begin{array}{l}\text { Item yg tdk } \\
\text { sesuai jml }\end{array}$ & $\begin{array}{l}\% \mathrm{jml} \\
\text { yg tdk } \\
\text { sesuai }\end{array}$ & $\begin{array}{l}\text { Ket. } \\
\text { Hasil }\end{array}$ \\
\hline \multirow[t]{25}{*}{ AMS } & 36 & 23 & & & & & \\
\hline & & & 13 & 1) 8 & Faktu Oint & $100 \%$ & BURUK \\
\hline & & & & & Pantozol 20mg tab & $20 \%$ & BAIK \\
\hline & & & & 2) 12 & ProlactaDHA kap & $100 \%$ & BURUK \\
\hline & & & & 3) 34 & Kloderma Oint & $100 \%$ & BURUK \\
\hline & & & & & Proris suppos & $100 \%$ & BURUK \\
\hline & & & & 4) 40 & Constantia drop & $70 \%$ & BURUK \\
\hline & & & & 5) 40 & Omeprazole Kap & $80 \%$ & BURUK \\
\hline & & & & & Faktu Oint & $50 \%$ & BURUK \\
\hline & & & & & Oxoferin Sol & $100 \%$ & BURUK \\
\hline & & & & & Narfoz 4mg Tab & $100 \%$ & BURUK \\
\hline & & & & 6) 17 & Pyravit Syr & $100 \%$ & BURUK \\
\hline & & & & & Scabimite $30 \mathrm{gr} \mathrm{Cr}$ & $100 \%$ & BURUK \\
\hline & & & & & Zamel drop & $100 \%$ & BURUK \\
\hline & & & & 7) 39 & ProlactaDHA kap & $100 \%$ & BURUK \\
\hline & & & & & Pantozol 40mg tab & $50 \%$ & BURUK \\
\hline & & & & & Praxion drop & $100 \%$ & BURUK \\
\hline & & & & & Salbuven tab & $100 \%$ & BURUK \\
\hline & & & & & Narfoz 8mg Tab & $100 \%$ & BURUK \\
\hline & & & & & Breathy Nasaldrop & $100 \%$ & BURUK \\
\hline & & & & & Iprox suspensi & $100 \%$ & BURUK \\
\hline & & & & 8) 11 & Faktu Oint & $100 \%$ & BURUK \\
\hline & & & & & Pyravit Syr & $100 \%$ & BURUK \\
\hline & & & & & Salbuven tab & $100 \%$ & BURUK \\
\hline & & & & 9) 2 & Narfoz 4mg amp & $100 \%$ & BURUK \\
\hline
\end{tabular}

10) 35 \begin{tabular}{lcc} 
Narfoz 8mg amp & $100 \%$ & Buruk \\
Ryvel Syr & $2 \%$ & BAIK \\
Metvell Tab & $20 \%$ & BAIK \\
Scabimite 30gr Cr & $100 \%$ & BURUK \\
Narfoz 4mg Tab & $100 \%$ & BURUK \\
Faktu suppos & $100 \%$ & BURUK \\
velutine Nebules & $50 \%$ & BURUK \\
Cetirizin Tab & $100 \%$ & BURUK \\
Pantozol 40mg & & \\
tab & $20 \%$ & BAIK \\
Ranivel Syr & $50 \%$ & BURUK \\
Drhydralite Sol & $50 \%$ & BURUK \\
Praxion drop & $100 \%$ & BURUK \\
Salbuven tab & $100 \%$ & BURUK \\
Faktu Oint & $100 \%$ & BURUK \\
Narfoz 8mg Tab & $100 \%$ & BURUK \\
Zamel Drop & $100 \%$ & BURUK \\
\hline
\end{tabular}




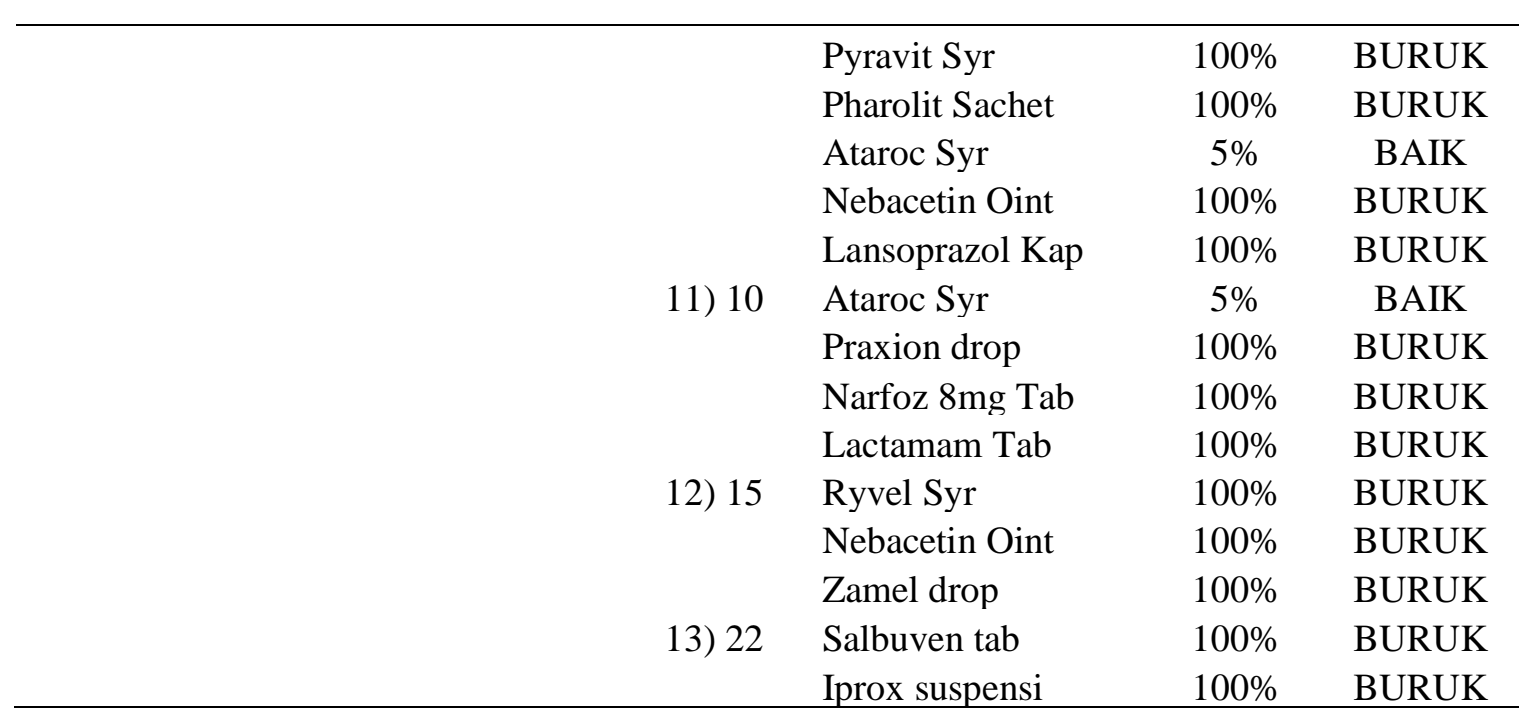

Tabel 5. Jumlah Sediaan Tidak Sesuai Pesanan PT. APL

\begin{tabular}{|c|c|c|c|c|c|c|c|}
\hline $\begin{array}{l}\text { Nama PBF } \\
(\mathrm{PT})\end{array}$ & $\begin{array}{l}\text { Jml } \\
\text { Po }\end{array}$ & $\begin{array}{l}\text { Jml } \\
\text { yg } \\
\text { sesuai } \\
\text { PO }\end{array}$ & $\begin{array}{l}\text { Item yg } \\
\text { jml tdk } \\
\text { sesuai }\end{array}$ & $\begin{array}{l}\text { Item yg } \\
\text { dipesan }\end{array}$ & $\begin{array}{l}\text { Item yg tdk } \\
\text { sesuai jml }\end{array}$ & $\begin{array}{l}\% \\
\text { jml } \\
\text { yg } \\
\text { tdk } \\
\text { sesuai }\end{array}$ & $\begin{array}{l}\text { Ket. } \\
\text { Hasil }\end{array}$ \\
\hline \multirow[t]{17}{*}{ APL } & 40 & 33 & & & & & \\
\hline & & & 7 & 1)15 & $\begin{array}{l}\text { Nexium 40mg } \\
\text { Tab }\end{array}$ & $50 \%$ & BURUK \\
\hline & & & & & Maltofer drop & $100 \%$ & BURUK \\
\hline & & & & & $\begin{array}{l}\text { Cygest } 400 \mathrm{mg} \\
\text { supp }\end{array}$ & $100 \%$ & BURUK \\
\hline & & & & & Maltofer Tab & $100 \%$ & BURUK \\
\hline & & & & & Mebo Oint & $100 \%$ & BURUK \\
\hline & & & & & Atopiclair $\mathrm{Cr}$ & $100 \%$ & BURUK \\
\hline & & & & 2) 5 & Extrace $100 \mathrm{mg}$ & $100 \%$ & BURUK \\
\hline & & & & & mederma $\mathrm{Cr}$ & $100 \%$ & BURUK \\
\hline & & & & 3)19 & Maltofer drop & $100 \%$ & BURUK \\
\hline & & & & 4)10 & Zincpro Syr & $100 \%$ & BURUK \\
\hline & & & & & $\begin{array}{l}\text { Flagyl 500mg } \\
\text { Tab }\end{array}$ & $100 \%$ & BURUK \\
\hline & & & & 5) 13 & Sangobion drop & $100 \%$ & BURUK \\
\hline & & & & 6) 34 & OBH combi Syr & $100 \%$ & BURUK \\
\hline & & & & & Prodiva gel & $100 \%$ & BURUK \\
\hline & & & & & Maltofer Fol Tab & $50 \%$ & BURUK \\
\hline & & & & 7) 15 & Sangobion drop & $100 \%$ & BURUK \\
\hline
\end{tabular}


Tabel 6. Jumlah Sediaan Tidak Sesuai Pesanan PT. BSP

\begin{tabular}{|c|c|c|c|c|c|c|c|}
\hline $\begin{array}{l}\text { Nama } \\
\text { PBF (PT) }\end{array}$ & $\begin{array}{r}\text { Jml } \\
\mathrm{PO}\end{array}$ & $\begin{array}{l}\text { Jml yg } \\
\text { sesuai PO }\end{array}$ & $\begin{array}{l}\text { Item yg } \\
\text { jml tdk } \\
\text { sesuai }\end{array}$ & $\begin{array}{l}\text { Item yg } \\
\text { dipesan }\end{array}$ & $\begin{array}{l}\text { Item yg tdk } \\
\text { sesuai jml }\end{array}$ & $\begin{array}{l}\% \mathrm{jml} \\
\text { yg tdk } \\
\text { sesuai }\end{array}$ & $\begin{array}{l}\text { Ket. } \\
\text { Hasil }\end{array}$ \\
\hline \multirow[t]{17}{*}{ BSP } & 38 & 27 & & & & & \\
\hline & & & 11 & 1) 28 & Pumpitor Kap & $100 \%$ & BURUK \\
\hline & & & & & Vosedon suspensi & $100 \%$ & BURUK \\
\hline & & & & 2) 41 & Ocuson Tab & $100 \%$ & BURUK \\
\hline & & & & 3) 14 & Ocuson Tab & $100 \%$ & BURUK \\
\hline & & & & 4) 42 & Ocuson Tab & $100 \%$ & BURUK \\
\hline & & & & 5) 33 & Ocuson Tab & $100 \%$ & BURUK \\
\hline & & & & 6) 5 & Ocuson Tab & $100 \%$ & BURUK \\
\hline & & & & 7) 32 & Epexol Tab & $100 \%$ & BURUK \\
\hline & & & & & Sanexon 16mg Tab & $100 \%$ & BURUK \\
\hline & & & & 8) 10 & Epexol drop & $100 \%$ & BURUK \\
\hline & & & & & Sanexon 16mg Tab & $100 \%$ & BURUK \\
\hline & & & & 9) 1 & Sanexon 16mg Tab & $100 \%$ & BURUK \\
\hline & & & & 10) 35 & Epexol Syr & $100 \%$ & BURUK \\
\hline & & & & & Cerini drop & $100 \%$ & BURUK \\
\hline & & & & & Epexol drop & $100 \%$ & BURUK \\
\hline & & & & 11) 9 & Sanexon $16 \mathrm{mg}$ Tab & $100 \%$ & BURUK \\
\hline
\end{tabular}

Tabel 7.Jumlah Sediaan Tidak Sesuai Pesanan PT. DNR

\begin{tabular}{lclllllc}
\hline $\begin{array}{l}\text { Nama } \\
\text { PBF (PT) }\end{array}$ & Jml & $\begin{array}{l}\text { Jml yg } \\
\text { sesuai } \\
\text { PO }\end{array}$ & $\begin{array}{l}\text { Item yg } \\
\text { jml tdk } \\
\text { sesuai }\end{array}$ & $\begin{array}{l}\text { Item yg } \\
\text { dipesan }\end{array}$ & $\begin{array}{l}\text { Item yg tdk sesuai } \\
\text { jml }\end{array}$ & $\begin{array}{c}\% \text { jml yg } \\
\text { tdk sesuai }\end{array}$ & Ket. \\
DNR & PO & & & & & & Hasil \\
& 8 & 7 & 1 & 1) 8 & Oligocare Tab & $100 \%$ & BURUK \\
\hline
\end{tabular}

Tabel 4.8.Jumlah Sediaan Tidak Sesuai Pesanan PT. Enseval

\begin{tabular}{|c|c|c|c|c|c|c|c|}
\hline $\begin{array}{l}\text { Nama } \\
\text { PBF } \\
\text { (PT) }\end{array}$ & $\begin{array}{r}\text { Jml } \\
\text { PO }\end{array}$ & $\begin{array}{l}\text { Jml yg } \\
\text { sesuai } \\
\text { PO }\end{array}$ & $\begin{array}{l}\text { Item yg } \\
\text { jml tdk } \\
\text { sesuai }\end{array}$ & $\begin{array}{l}\text { Item yg } \\
\text { dipesan }\end{array}$ & $\begin{array}{l}\text { Item yg tdk } \\
\text { sesuai jml }\end{array}$ & $\begin{array}{l}\% \mathrm{jml} \mathrm{yg} \\
\text { tdk sesuai }\end{array}$ & $\begin{array}{l}\text { Ket. } \\
\text { Hasil }\end{array}$ \\
\hline \multirow[t]{8}{*}{ Enseval } & 41 & 34 & & & & & \\
\hline & & & 7 & 1) 9 & Cefspan Syr & $100 \%$ & BURUK \\
\hline & & & & 2) 27 & Cefspan Syr & $50 \%$ & BURUK \\
\hline & & & & 3) 21 & Kalnex Tab & $100 \%$ & BURUK \\
\hline & & & & 4) 8 & Liprolax Tab & $100 \%$ & BURUK \\
\hline & & & & 5) 4 & Neo Gynoxa Supp & $100 \%$ & BURUK \\
\hline & & & & 6) 5 & Cefspan Syr & $20 \%$ & BAIK \\
\hline & & & & 7) 9 & Profertil Tab & $100 \%$ & BURUK \\
\hline
\end{tabular}


Tabel 9. Jumlah Sediaan Tidak Sesuai Pesanan PT. MPI

\begin{tabular}{|c|c|c|c|c|c|c|c|}
\hline $\begin{array}{l}\text { Nama } \\
\text { PBF } \\
\text { (PT) }\end{array}$ & $\begin{array}{r}\mathrm{Jml} \\
\mathrm{PO}\end{array}$ & $\begin{array}{l}\text { Jml yg } \\
\text { sesuai } \\
\text { PO }\end{array}$ & $\begin{array}{l}\text { Item } \\
\text { yg jml } \\
\text { tdk } \\
\text { sesuai }\end{array}$ & $\begin{array}{l}\text { Item } \\
\text { yg } \\
\text { dipesa } \\
n\end{array}$ & $\begin{array}{l}\text { Item yg tdk } \\
\text { sesuai jml }\end{array}$ & $\begin{array}{l}\% \\
\mathrm{jml} \\
\mathrm{yg} \\
\text { tdk } \\
\text { sesua } \\
\mathrm{i}\end{array}$ & $\begin{array}{l}\text { Ket. } \\
\text { Hasil }\end{array}$ \\
\hline \multirow[t]{3}{*}{ MPI } & 9 & 7 & & & & & \\
\hline & & & 2 & $\begin{array}{l}\text { 1) } 22 \\
\text { 2) } 6\end{array}$ & $\begin{array}{l}\text { Lasgan Kap } \\
\text { Elox Cr }\end{array}$ & $\begin{array}{l}100 \% \\
10 \%\end{array}$ & $\begin{array}{l}\text { BURUK } \\
\text { BAIK }\end{array}$ \\
\hline & & & & & Sirplus Syr & $100 \%$ & BURUK \\
\hline
\end{tabular}

Tabel 4.10. Jumlah Sediaan Tidak Sesuai Pesanan PT. PARIT

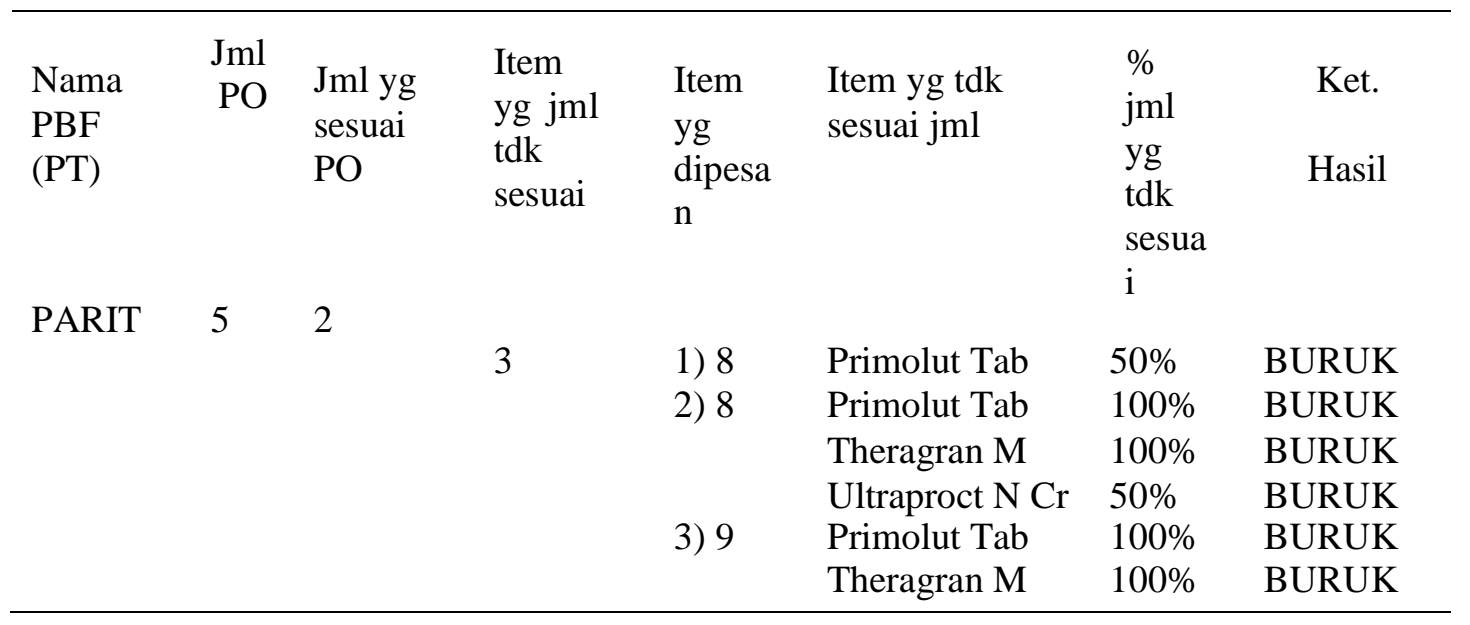

Tabel 15. Jumlah Sediaan Tidak Sesuai PT. PV

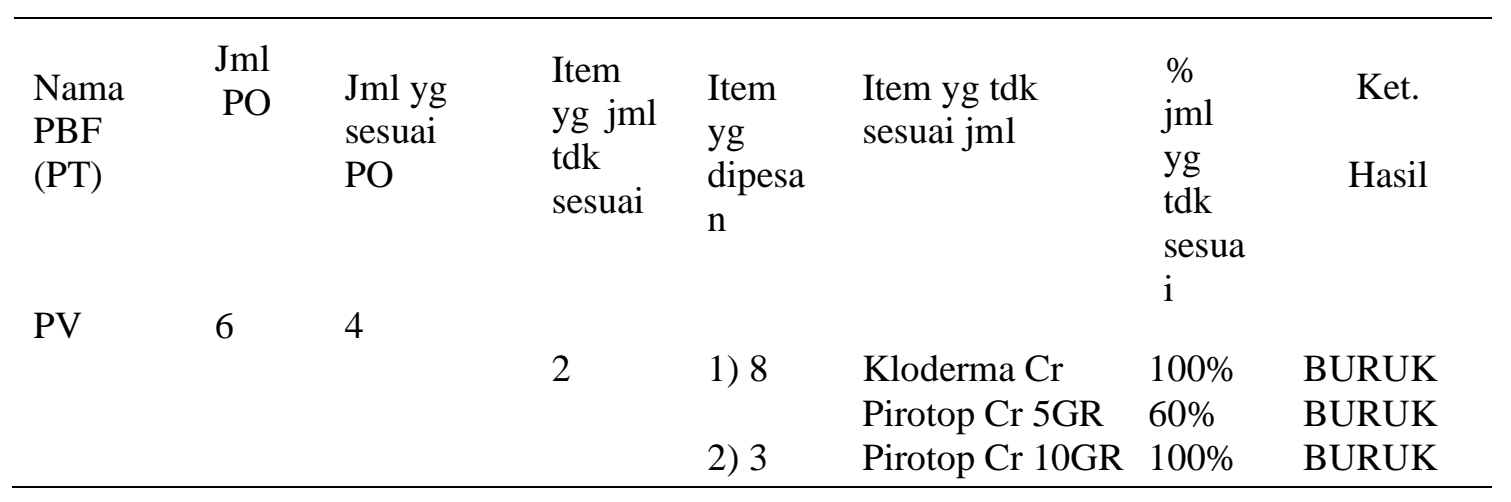





\section{PEMBAHASAN}

Pengelolaan obat merupakan salah satu manajemen farmasi di rumah sakit yang sangat penting dalam penyediaan pelayanan secara keseluruhan, karena tidak efisien dan tidak lancarnya pengelolaan obat akan memberikan dampak negatif terhadap rumah sakit, baik secara medik, sosial maupun secara ekonomi.

Berdasarkan Peraturan Menteri Kesehatan Republik Indonesia Nomor 1148/MENKES/PER/VI/2011 Tentanng Pedagang Besar Farmasi pada Pasal 1, Pedagang Besar Farmasi (PBF) adalah perusahaan berbentuk badan hukum yang memiliki izin utuk pengadaan, penyimpanan, penyaluran obat dan atau bahan obat dalam jumlah besar sesuai ketentuan peraturan perundangundangan.

Berdasarkan tabel 1, dapat diketahui bahwa dari 302 jumlah surat permintaan pembelian untuk presentase ketepatan waktu adalah 97,35\% dan yang tidak tepat waktu yaitu $2,64 \%$ dengan 6 distributor yang service level supplier nya buruk terhadap waktu tunggu pesanan karena melebihi batas standar yang ditetapkan yaitu : 1) PT. AAM, 2) PT. APL, 3) PT. BSP, 4) PT. KBF, 5) PT. MPI, 6) PT. PV.

Berdasarkan data yang telah di ambil pada tabel 1, terdapat 7 Pedagang Besar Farmasi (PBF) PT. AMS, PT DNR, PT. ENSEVAL, PT. GAW, PT. KF, PT. MBS, PT. PARIT, yang mengirim barang sesuai dengan waktu yang sudah ditentukan oleh Instalasi Farmasi RSIA Kemang Medical Care yakni $1-3$ hari dan terdapat 6 Pedagang Besar Farmasi (PBF) PT. AAM, PT. APL, PT. BSP, PT. KBF, PT. MPI, PT. PV, yang mengirim barang tidak sesuai waktu yang ditentukan oleh RSIA Kemang Medical Care yakni $4-5$ hari dimana waktu yang sudah ditentukan oleh RSIA Kemang Medical Care yakni $1-3$ hari dihitung dari waktu pemesanan sampai barang diterima oleh gudang farmasi RSIA Kemang Medical Care

Penilaian kerja distributor merupakan kegiatan yang dilakukan 
oleh suatu perusahaan untuk menilai

potensi dan kinerja distributor.

Mengukur kinerja supplier dapat

memberikan informasi yang diperlukan

dalam mengambil keputusan,

mengontrol, dan mengarahkan suatu

kegiatan operasional. Manager

Perusahaan juga dapat mengarahkan

supplier untuk melakukan perbaikan

dan meningkatkan kinerja sehingga

dapat mencapai tujuan bersama.

\section{Indikator Tingkat Layanan}

adalah ukuran tingkat layanan yang disediakan oleh penyedia layanan kepada pelanggan. Standar service level yang telah ditetapkan antara Instalasi Farmasi RSIA Kemang Medical Care dengan pihak distributor adalah untuk ketepatan waktu maksimal 3 hari dihitung dari waktu pemesanan sampai barang diterima oleh bagian Gudang, kesesuaian jenis/ item adalah $80 \%$, sedangkan kesesuaian jumlah barang tidak ditetapkan standarnya.

Berdasarkan pada tabel 2, presentase service level supplier terhadap kesesuain item atau jenis sediaan yang dikirim oleh Pedagang

Besar Farmasi (PBF), terdapat Pedagang Besar Farmasi (PBF) yang pernah mengirim sediaan farmasi tidak sesuai item / jenis yang dipesan dengan hasil presentase service level supplier berkisar antara $85,55 \%$ (PT. Parit) 98,43\% (PT. DNR).

Berdasarkan tabel 3 hingga table 15, presentase service level supplier terhadap jumlah sediaan farmasi yang dikirim terdapat Pedaang Besar Farmasi (PBF) yang mengirim sediaan farmasi tidak sesuai dengan yang diminta. Presentase kesesuian barang yakni antara $2 \%-100 \%$.

Berdasarkan tabel 16, faktor penyebab keterlambatan dan ketidak sesuaian jenis / item serta jumlah sediaan farmasi yang dikirim oleh Pedagang Besar Farmasi (PBF) disebabkan oleh kurangnya jumlah barang dalam pengiriman.

Sejauh ini masalah yang sering ditemukan yang berkaitan dengan Pedagang Besar Farmasi (PBF) adalah ketidaktepatan waktu dalam penerimaan 
dari Pedagang Besar Farmasi (PBF) hal

ini dapat menimbulkan dampak yang

negatif bagi pelayanan di Rumah Sakit.

Alasan yang ditemukan dilapangan

mengapa terjadi ketidaktepatan waktu

dalam pengiriman adalah terjadinya

kekosongan barang di gudang Pedagang

Besar Farmasi (PBF) dan tidak adanya

kurir pengantar di waktu tersebut

sehingaa barang tidak bisa diproses dan

dikirim dengan tepat waktu.

\section{KESIMPULAN}

1. Lead time (waktu tunggu) obat yang dibutuhkan oleh bagian Gudang Instalasi Farmasi RSIA Kemang Medical Care mulai dari pemesanan di Pedagang Besar Farmasi (PBF), kemudian pengiriman barang sampai dengan penerimaan barang, waktu yang dibutuhkan adalah $1-5$ hari. Berdasarkan kerja sama dengan 13 Pedagang Besar Farmasi (PBF) hanya terdapat 7 Pedagang Besar Farmasi (PBF) yang memiliki pelayanan baik terhadap waktu tunggu pesanan yaitu 1) PT. AMS, 2) PT. DNR, 3) PT. Enseval, 4) PT. GAW, 5) PT. KF, 6) PT. KBF, 7) PT. Parit.
2. Presentase Service Level Supplier yang di dapat terhadap kesesuian jenis pesanan / item pesanan yang diminta dengan barang yang diterima oleh Gudang Instalasi Farmasi RSIA Kemang Medical Care adalah $85,55 \%-98,43 \%$.

3. Presentase Service Level Supplier yang di dapat terhadap kesesuaian jumlah pesanan barang yang diminta dengan barang yang diterima oleh Gudang Instalasi Farmasi RSIA Kemang Medical Care adalah berkisar antara 2\% - 100\%. Berdasarkan kerja sama dengan 13 Pedagang Besar Farmasi (PBF) untuk kesesuaian jenis / item serta jumlah pesanan semua Pedagang Besar Farmasi (PBF) memiliki pelayanan yang buruk.

\section{DAFTAR PUSTAKA}

Kearney, K.T.; Torelli, F. (2011). "The SLA Model". In Wieder, P.; Butler, J.M.; Theilmann, W.; Yahyapour, R. (eds.). Service Level Agreements for Cloud Computing.

Paradipta, A., Fahridho, A., Laduni, D.H., Sandi, F., Nasution. J., 2013. Sistem Evaluasi Kinerja Supplier di PT XYZ, 3.

Peraturan Menteri Kesehatan Republik Indonesia, Nomor 72 Tahun 2016 Tentang Standar Pelayanan Kefarmasian di Rumah Sakit. 
Pratiwi, A., 2019. Stock Out Obat di Gudang Logistik Perbekes RSIJ Cempaka Putih pada Triwulan I Tahun 2009, Skripsi, Fakultas Kesehatan Masyarakat, Universitas Indonesia, Jakarta.

Profil Rumah Sakit Ibu dan Anak Kemang Medical Care, Jakarta.

Samson, K., Jonathan, M., Mulli, W., Ruth, N., Tabby, G., 2013. The Effect of Supplier Quality Management on Organizational Performance: A Survey of Supermarkets in Kakamega Town. International Journal of Business and Commerce, 72.

Saputera, M.M.A, 2016. Evaluasi Pengelolaan Obat Tahap Seleksi dan Perencanaan di Era Jaminan Kesehatan Nasional di RSUD H. Hasan Baseri Kandangan Tahun 2014. Jurnal Ilmiah Ibnu Sina I (2), 249.
Sivapornpunlerd, N., 2014. Supplier Performace Evaluation: A Case Study of Thai Offshore Oil \& Gas Exploration and Production Company. ASBBS Annual Conference: Las Vegas, 647.

Trianto, R., 2013. Perancangan dan Implementasi Sistem Penilaian Kinerja Distributor Susu Menggunakan Logika Fuzzy (Studi Kasus: Koperasi Wahyu Agung Kab. Semarang), Skripsi, Fakultas Teknologi Informasi, Universitas Kristen Satya Wacana, Salatiga.

Undang - Undang dan Peraturan Pemerintah Republik Indonesia, Nomor 51 Tahun 2009 tentang Pekerjaan Kefarmasian.

Undang - Undang Republik Indonesia, Nomor 36 Tahun 2009 tentang Kesehatan.

Undang - Undang Republik Indonesia, Nomor 44 Tahun 2009 tentang Rumah Sakit. 